\title{
Influence of entrepreneurial orientation: How open innovation and risk governance affects firm performance
}

\author{
Stefanny Magdalena Susanto
}

Stefannymagdalena55@gmail.com

Entrepreneurial Orientation adalah proses pembuatan strategi yang mewakili kebijakan dan praktik sebagai dasar dalam bertindak dan mengambil keputusan dalam berwirausaha (Zhang, O'Kane, \& Chen, 2020). Dalam penerapannya, Entrepreneurial Orientation sendiri selalu mengedepankan karakter open innovation dan pengelolaan risikonya dengan harapan dapat mengembangkan organisasi / perusahaan di semua tingkat khususnya terhadap unit bisnisnya (Hughes \& Hodgkinson, 2020). Open Innovation yang dimaksud adalah sebuah proses pemanfaatan ide-ide inovatif yang berasal dari eksternal perusahaan sehingga dapat mempercepat inovasi dan memperluas pasar suatu perusahaan (Lyu, Zhu, Han, He, \& Bao, 2020). Open Innovation berpihak pada perubahan dan mendukung kegiatan yang berkaitan dengan pemanfaatan berbagai inovasi seperti pengembangan produk / jasa baru, dan penciptaan nilai pelanggan yang unggul (Tajeddini, Martin, \& Ali, 2020). Sedangkan, Pengelolaan Risiko yang dimaksud adalah proses dan mekanisme dimana keputusan berisiko diambil dan diimplementasikan dalam suatu perusahaan (Krauß \& Bremer, 2020). Hal ini yang akhirnya menyebabkan tingkat pengambilan risiko lebih tinggi dibandingkan dengan perusahaan yang lebih konservatif (Kihm \& Kamal, 2020).

Variabel yang digunakan (Pratono, 2018a) dalam penelitiannya untuk menjelaskan konsep Open Innovation adalah pengembangan produk (Product Development). Dari analisis yang dilakukan, dapat kita simpulkan bahwa keberhasilan pengembangan produk tidak terlepas dari konsep Open Innovation, hal ini berhubungan dengan karakter perusahaan yang lebih partisipatif, tersebar dan terpusat pada inovasi serta mempunyai competitive advantage dan open resource juga didalamnya. Sedangkan dalam pengukuran tingkat pengelolaan risiko (Risk Governance), variabel yang digunakan (Pratono, 2018b) dalam penelitiannya adalah Risk-Taking Behaviour yang didukung dengan pengukuran subyektif likert scale dari skala satu sampai tujuh. Berdasarkan berbagai tolak ukur yang ada, tujuan dari analisis (Pratono, 2018b) ini yaitu untuk mendorong perusahaan dalam membangun orientasi pengelolaan risiko agar dapat bertindak tegas, berpikir secara luas, mampu meminimalisir risiko dalam setiap permasalahan yang muncul dan terus berkembang dalam ketidakpastian. 


\section{Bibliography}

Hughes, M., \& Hodgkinson, I. (2020). The multi-level effects of corporate entrepreneurial orientation on business unit radical innovation and financial performance. Long Range Planning, 43, 24-63.

Kihm, S., \& Kamal, R. (2020). Bridging the gap between management and finance: entrepreneurial orientation and idiosyncratic risk. Managerial Finance, 58, 307-358.

Krauß, W., \& Bremer, S. (2020). The role of place-based narratives of change in climate risk governance. Climate Risk Management, 28, 16-21.

Lyu, Y., Zhu, Y., Han, S., He, B., \& Bao, L. (2020). Open innovation and innovation "Radicalness"-the moderating effect of network embeddedness. Technology in Society, 62, 80-92.

Pratono, A. H. (2018a). Network structure and open innovation: the role of trust in product development. International Journal of Business Innovation and Research, 15(1), 44-61.

Pratono, A. H. (2018b). Does firm performance increase with risk-taking behavior under information technological turbulence?: Empirical evidence from Indonesian SMEs. The Journal of Risk Finance, 19(4), 361-378.

Tajeddini, K., Martin, E., \& Ali, A. (2020). Enhancing hospitality business performance: The role of entrepreneurial orientation and networking ties in a dynamic environment. International Journal of Hospitality Management, 90, 278-319.

Zhang, J. A., O'Kane, C., \& Chen, G. (2020). Business ties, political ties, and innovation performance in Chinese industrial firms: The role of entrepreneurial orientation and environmental dynamism. Journal of Business Research, 121, 254-267. 